\title{
FARMERS' LIVELIHOOD, RISK EXPECTATIONS, AND HOMESTEAD WITHDRAWAL POLICY: EVIDENCE ON JINJIANG PILOT OF CHINA
}

\author{
Fachao LIANG (1) ${ }^{1}$, Caiyun LIN ${ }^{1}$, Sheng-Hau LIN (1D) 2,* \\ ${ }^{1}$ School of Political and Public Administration, Huaqiao University, Quanzhou, China \\ ${ }^{2}$ Department of Public Administration, Law School, Ningbo University, Ningbo, China
}

Received 29 June 2021; accepted 14 December 2021; first published online 21 January 2022

\begin{abstract}
Although exploring the homestead withdrawal (HW) mechanism can optimize the allocation of land resource elements, the livelihood sources of farmers will change and face different sources of risk. Many studies have explored various factors affecting the HW. However, studies simultaneously exploring the relationship among farmers' internal livelihood capital and external risk prevention capabilities and HW including differences among various HW models are still limited. The present study constructed a simple theoretical framework and used the probit model to analyze the decision-making behavior of 367 farmers in the Jinjiang Pilot in Fujian Province of China. Specifically, this study explored the impact of farmers' livelihoods including natural, financial, and human capitals and risk expectations. Such risk expectations involve living conditions, social security, residential environment, and psychological conditions on HW in asset replacement, index replacement, and monetary compensation model. The empirical findings indicated that the farmers' livelihoods and risk expectations have inconsistent effects on farmers' HW decision-making in all the models, except for risk expectations. In other words, social security and residential environment have a significant inhibitory effect. These results implied that differentiated policies for HW should be considered to enhance the farmer's sustainable livelihood capacity and controllability of risk.
\end{abstract}

Keywords: homestead withdrawal, livelihood, risk expectations, different models, China.

\section{Introduction}

The world's urban population is expected to increase from 2.6 billion in 2000 to 5 billion in 2030 , and the rapid growth of the population has produced a large demand for urban land (Kumar et al., 2021). A large number of the rural population has poured into cities and towns to become citizens, occupying limited urban land resources (Shan \& Feng, 2018). Once the population decreases, the self-sufficient rural villages will be hollowed out by industrial decline, and abandoned land will be evident around the world (Donaldson \& Lord, 2018; Loures \& Vaz, 2018; Shan \& Feng, 2018). This phenomenon is particularly prominent in rural areas of China because of rapid urbanization (Zhou et al., 2020b), highlighting a dilemma between considerable idle rural homesteads and urban land supply (Cao et al., 2019). The rural economic structure and function of homesteads are gradually transforming. The phenomena of "multiple houses in one household" and "building new without demolishing the old" are more common in rural than urban areas. Therefore, problems such as idle and inefficient use of rural homesteads have become prominent (Sun et al., 2018). According to statistics, China's rural population decreased by $13 \%$ from 1997 to 2007; however, the per capita land area increased by $4 \%$, and the vacancy rate of homesteads reached $10-15 \%$ (Chen et al., 2017). Homestead withdrawal (HW) implies that farmers abandon their right to use rural homesteads owned under the guidance of local governments or rural collective economic organizations. In turn, they receive money or new houses as compensation. Exploring the HW mechanism can not only optimize the allocation of land resource elements but also promote rural modernization (Sun et al., 2018), thereby achieving rural revitalization (Zhang et al., 2020).

Unlike many western countries (Chen et al., 2017) and as a welfare system arrangement in rural China, a homestead is a basic and important livelihood resource for most farmers. After HW, farmers' sources of livelihood and livelihood structure will change accordingly to allocate the livelihood resources (Chen et al., 2018). A good land loss compensation mechanism may increase farmers' economic capacity and change their livelihoods, social

*Corresponding author. E-mail: shenghauhlin@nbu.edu.cn

Copyright $\odot 2022$ The Author(s). Published by Vilnius Gediminas Technical University

This is an Open Access article distributed under the terms of the Creative Commons Attribution License (https://creativecommons.org/licenses/by/4.0/), which permits unrestricted use, distribution, and reproduction in any medium, provided the original author and source are credited. 
arrangements, and lifestyles. The lack of social and economic security, employment opportunities, and conversion of agricultural land is most likely to trigger conflicts between farmers and surrounding communities. They are vulnerable to suffering and psychological, cultural, and social exclusion, thereby being unable to integrate into urban life (Kumar et al., 2021). Further, farmers face unexpected risk threats after HW, thereby affecting the willingness to withdraw and the efficiency of HW policy promotion. Farmers are the main actors in the activities of HW. Hence, exploring the HW model from the perspective of livelihood capital and risk expectations will ensure the balanced development of farmers' welfare. Moreover, such a process can help clarify the effectiveness of the current HW model to optimize and perfect the formulation of the HW model in the future. China's HW experience will also help other developing countries to formulate rural land policies related to sustainable rural development.

Previous studies have extensively explored the HW from the farmers' perspectives and analyzed the issue from macro and micro levels. Examples of the former include economic, societal, and institutional policies, while those of the latter include individual characteristics of farmers and resource endowments. Internationally, many scholars have focused on various factors influencing HW (Chen et al., 2017; Huang et al., 2018; Shan \& Feng, 2018; Sun et al., 2018; Cao et al., 2019; Fan \& Zhang, 2019; Tang et al., 2020). Some researchers have also investigated issues related to farmers' livelihood capital, including cultivated land transfer (Huang et al., 2017; Kumar et al., 2021; Yang et al., 2021), livelihood vulnerability (Baffoe \& Matsuda, 2018), resettlement and relocation (Liu et al., 2020), or the perspective of sustainable development (You \& Zhang, 2017; Deng et al., 2020). Other researchers have explored livelihood strategies from different village types (Xu et al., 2019), ethnic minorities (Mao et al., 2020), small-scale farmers ( $\mathrm{Li}$ et al., 2020), or earthquake-affected areas (Zhou et al., 2021). Kuang et al. (2020) studied the impact of farmers' livelihood assets on their livelihood risks and adaptation strategies. Comparatively, HW has been explored predominantly by domestic scholars. The value perceptions, property rights preferences, and dependence on lands of different rural households differ in the context of the gradual transformation of rural households' development mode and the differentiation of rural households' livelihoods. Some researchers have explored the impact of farmers' livelihood capital, livelihood transformation, and the heterogeneity of livelihood assets on HW (Wang et al., 2019, 2020). Alternatively, risk expectations impact the psychological perception of farmers facing changes in external conditions. Some researchers explored the impact of farmers' risk expectations, perceived value, and subjective norms on HW (Sun et al., 2019; Zhou et al., 2021; Li \& Zhang, 2019).

However, till date no researcher has simultaneously explored the impact of livelihood capital and risk expectations on HW. Moreover, as different areas of China have explored differentiated HW models, significant differences are observed in the effectiveness of different models in protecting rural households' rights and interests and their distribution (Zhu et al., 2014; Wu \& Wu, 2020; Qu et al., 2021); consequently, a comparison of the different HW models is required. Therefore, in this study, we used the sustainable livelihood analysis (SLA) framework and planning behavior theory to construct a theoretical framework based on Jinjiang City, Fujian Province. The city is located in the southeastern coastal area of China and is a comprehensive pilot of China's new urbanization. In 2019, the urbanization level reached 67.4\% (Jinjiang Statistics Bureau, 2019). Then, in March 2015, the region started a pilot reform of the HW, and the significant policy performance formed the "Jinjiang Model" with the characteristics of the Jinjiang City. This region has three representative HW models-asset replacement, index replacement, and monetary compensation. In this research, we combined theory and empirical results to explore the impact of farmers' livelihood capital and risk expectations on their HW behavior. We also compared the differences among these three different models and recommended several policies.

The remaining sections of this research are arranged as follows. Section 1 presents the materials and methods and outlines the specific research framework and research process. Section 2 presents the empirical results, and Section 3 discusses the results. Last section outlines the conclusions and policy recommendations.

\section{Materials and methods}

\subsection{Theoretical framework}

This study aimed to explore the impact of farmers' livelihoods and risk expectations on their HW decision-making among different models. The SLA framework was first proposed by the UK Department for International Development (DFID) in 1998 (Department for International Development, 1999). This framework provides ideas for people to consider and analyze poverty and livelihood issues (Allison \& Horemans, 2006; Cetinkaya et al., 2014). In addition to traditionally examining income poverty, the framework also emphasizes developing the ability to use one's own assets and achieve subsistence (Qu et al., 2021; Zhou et al., 2020a). The Chinese government also regards sustainable livelihoods as a measure to reduce poverty $(\mathrm{Li}$ et al., 2020). The framework covers five key types of capital, namely, natural, physical, human, financial, and social. This study primarily focuses on the impact of natural, financial, and human capitals on HW. Physical and social capitals are not considered because of the following reasons: (1) physical capital generally refers to the quantity of agricultural machinery and household durable consumer goods. The area of arable land in rural areas in economically developed areas is relatively scarce and large-scale agricultural production activities by machinery are rare. The quantity of durable consumer goods of households is 
the same, and the correlation with the willingness to HW is low. Therefore, as a reprehensive factor, financial capital should be sufficient. (2) Social capital is generally used to measure the households' participation in public affairs in the village or whether anyone in the family serves as the village cadre. According to many surveys and interviews with farmers, this study found that HW is less affected by social networks and social capital. Moreover, the study utilized the analytical thinking dimension of planned behavior theory. This theory believes that human behavior patterns are affected by the control of perceptual behavior and behavior attitudes. Perceptual behavior control reflects the endowment effects of human resources, opportunities, and others, that is, the livelihood capital structure of farmers. Then, behavior attitude reflects the value judgment of farmers, that is, farmers' risk expectations.

The differences in local conditions, resource endowments, and property rights arrangements of different HW models exert the main impacts on the welfare of farmers. Hence, we explored the differences among the three HW models in Jinjiang City, Fujian Province, China (Liang \& Lin, 2021), as follows:

Asset replacement model: Through the transfer of land ownership, the replacement of rural homesteads and high-rise properties occurs in urban planning areas between urban and rural areas. After withdrawal, the identity of farmer households will transition from rural to urban household registration. Then, farmers will no longer be involved in homestead distribution. This model is for farmers who have withdrawn from their homesteads to build urban houses and plan new communities. Housing replacement is based on the building area of the house. The differences between the houses that farmers need to pay for and the area that can be expanded at a low price are different according to the number of residential floors.

Index replacement model: Rearrangement and allocation of the index of the homestead are carried out through the following: purchase and storage of the homestead, movement within the scope of the village, the collective planning and construction of the village, and centralized resettlement and relocation. This model is organized by the village collectives according to the homestead area of the farmers. The top 20 farmers can replace the townhouses built by the village collectives. The remaining can be moved into the collectively built high-rise resettlement houses without changing their organizational membership.

Monetary compensation model: Rural land consolidation projects are combined to provide centralized resettlement or currency termination to guide farmers to withdraw from their homesteads with compensation. This model is suitable for multi-residential households, urban residents, and overseas Chinese groups. In the context of multi-party collaboration, this model was developed from three aspects. The first aspect provided one-off monetary compensation, and farmers who choose to end the currency will voluntarily give up membership in collective organizations. The second one built residential areas based on the significant urbanization trend to realize in-situ ur-

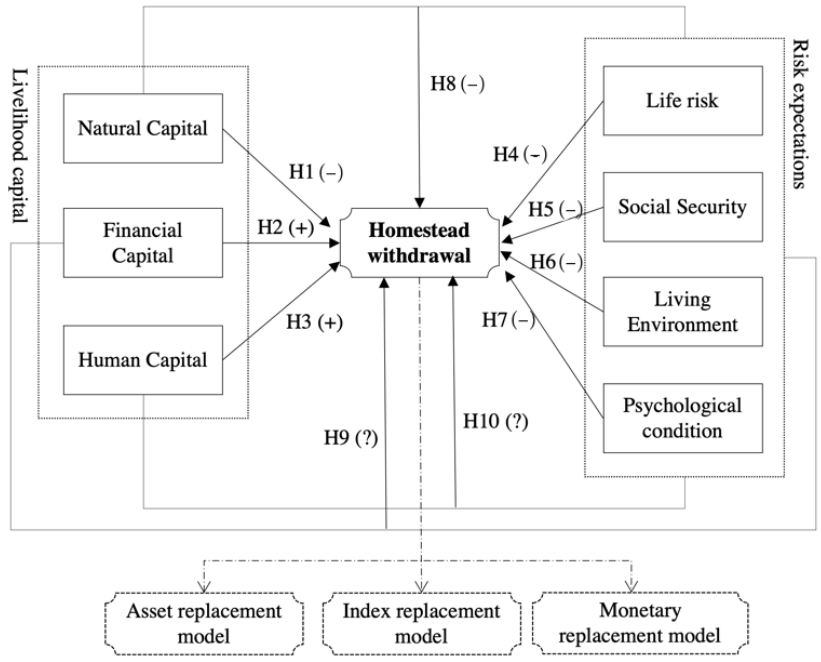

Figure 1. Theoretical framework and research hypotheses

banization through upstairs resettlement. Finally, the third aspect formed an urban construction land index for the refurbishment and development of the withdrawn homesteads, and the village collectives' newly reclaim land to balance arable land occupation and compensation.

Figure 1 shows the specific research theoretical framework and nine research hypotheses.

\subsubsection{Hypothesis of the impact of households' livelihoods on farmers' HW decision-making behavior}

Farmers' livelihoods are the choice opportunities that their families and individual resource endowments have. Their livelihoods are the basis not only for making production decisions but also for farmers' livelihood strategies to cope with their livelihood vulnerabilities and risk environments (Sun et al., 2020; Lin \& Guo, 2020; Kuang et al., 2020). Rural land has economic, social, and ecological functions and is the basic space where farmers families survive and develop (Wang \& Zhu, 2018). The source of livelihoods of farmers before the HW determines their dependence on the homestead, the degree of influence by the economic and social structures of the village, and strategy development. After HW, farmers will change their lifestyles and correspondingly face transformation and adaptability problems. Currently, the livelihood capital owned by farmers has a decisive effect on obtaining better employment opportunities and income channels. This livelihood capital is related to the appreciation of farmers' assets and changes in the welfare level (Huang \& Chen, 2016).

Natural capital refers to the natural resources and services that farmers rely on for survival and development (Li et al., 2020). Therefore, as farmers have more natural capital before the withdrawal of homesteads, their dependence on rural homesteads will intensify and possibly inhibit their willingness to withdraw. Conversely, when farmers have higher financial capital, such as greater nonagricultural income, they will have a stronger impact on the transfer of cultivated land (Yang et al., 2021). Similarly, natural capital may have a stronger influence on HW 
than financial capital. Finally, human capital refers to the personal knowledge, skills, health, and labor potential of farmers. Human capital is regarded as the main driving force for the migration of farmers to cities and can have a strong effect on the HW. The three research hypotheses are proposed in terms of livelihood capital as follows:

Hypothesis 1: Natural capital will inhibit farmers' HW decision-making behavior.

Hypothesis 2: Financial capital will promote farmers' HW decision-making behavior.

Hypothesis 3: Human capital will promote farmers' HW decision-making behavior.

\subsubsection{Hypothesis of the impact of risk expectations on farmers' HW decision-making behavior}

Sen's (1999) theory of feasible capability pointed out that the functional freedom of farmers should be clarified in terms of freedom of decision-making participation, economic conditions, social opportunities, transparency guarantees, and protective guarantees (Liang \& Lin, 2019; Zhu \& Cai, 2016; Yang et al., 2019). The risk expectation of farmer households refers to the uncertainty of long-term livelihoods and legal rights and interests of farmers who are the subject of risk-bearing after HW. The risk expectation of farmers is the cognition of risk during the transition, which is generated along with decision-making problems. The relevant mechanism is resettlement after HW, which can easily cause a series of structural social risks. First, in the market-oriented environment, the economic function of homesteads is becoming increasingly evident. Farmers lose their value functions after HW. Moreover, the living cost is increased after "going upstairs"; therefore, the living standards of farmers are affected (Shang Guan et al., 2017; Shi \& Yu, 2021). Second, under the dual structure of urban and rural areas, homesteads play an important protective function. In addition, the implementation of relevant policies has failed to effectively protect the employment of farmers and children's education $(\mathrm{Wu} \& \mathrm{Wu}$, 2021). Additionally, the social network that was originally rooted in the village collapses, and farmers face the needs and risks of social integration after moving into the new community (Hu et al., 2020). Finally, if the construction of resettlement houses and community planning lacks supervision, the living conditions of rural households may be damaged. When farmer households are expected to increase their risks, they will continue to reduce their efforts to complete their goals, which will inhibit HW. In general, risk expectations may reflect all aspects of life, social security, living environment, and individual psychological state. Therefore, the four research hypotheses were proposed in terms of risk expectations as follows:

Hypothesis 4: The life risk expectation will inhibit farmers' HW decision-making behavior.

Hypothesis 5: The social security risk expectation will inhibit farmers' HW decision-making behavior.

Hypothesis 6: The residential environment expectation will inhibit farmers' HW decision-making behavior.
Hypothesis 7: The psychological risk expectation will inhibit farmers' HW decision-making behavior.

\subsubsection{Hypothesis of the interaction impact between livelihood capital and risk expectations on farmers' HW decision-making behavior}

As "rational economic persons", farmers will comprehensively weigh their resource endowments and risk preferences to respond to HW and maintain sustainable livelihoods. According to different sources and structures of family livelihoods, differences exist in the risk's capacity and types of risk resistance. When combined with farmers' livelihoods and risk expectations, farmers can achieve utility maximization and preference stabilization, thereby weakening or strengthening their HW behavior decisionmaking (Zhang et al., 2016; Su et al., 2019). When farmers have more arable land and homestead resources, natural capital still plays an important role to protect their livelihoods. The additional uncertainty brought by risk expectations will strengthen the restraint of natural capital, thereby reducing farmers' HW. Moreover, when farmers have more natural financial capital to promote HW decision-making behavior because they resist economic risks, they may face failure to integrate into the new homestead to inhibit the promotion. Further, farmers with a higher level of education have relatively weakly dependent ability from homestead (Liang \& Lin, 2019). However, they have to consider the old-age security role from homesteads when considering the long-term livelihood of the entire family. Based on this, the interaction between financial or educational livelihoods and risk expectations is unpredictable. Therefore, three research hypotheses are proposed in terms of the interaction impact between livelihood capital and risk expectations on farmers' HW decision-making behavior as follows:

Hypothesis 8: The interaction between natural capital and risk expectations will intensify the suppression effect of farmers' HW decision-making behavior.

Hypothesis 9: The interaction impact between financial capital and risk expectations on farmers' HW decision-making behavior is unpredictable.

Hypothesis 10: The interaction impact between human capital and risk expectations on farmers' HW decisionmaking behavior is unpredictable.

\subsection{Empirical area}

To verify the proposed research hypotheses, farmer households in the $\mathrm{G}$ community, $\mathrm{Q}$ village, and $\mathrm{X}$ village in Jinjiang City, Fujian Province, China, were investigated (Figure 2). G community, Q village, and X village represent the asset replacement, the index replacement, and the monetary compensation models, respectively. Currently, Jinjiang City has withdrawn $263.17 \mathrm{hm}^{2}$ of homesteads through the three models, and the land saving rate has reached $44 \%$. The author team conducted multiple field surveys during 2019-2020. The team collected information about the area of HW, compensation standards, 


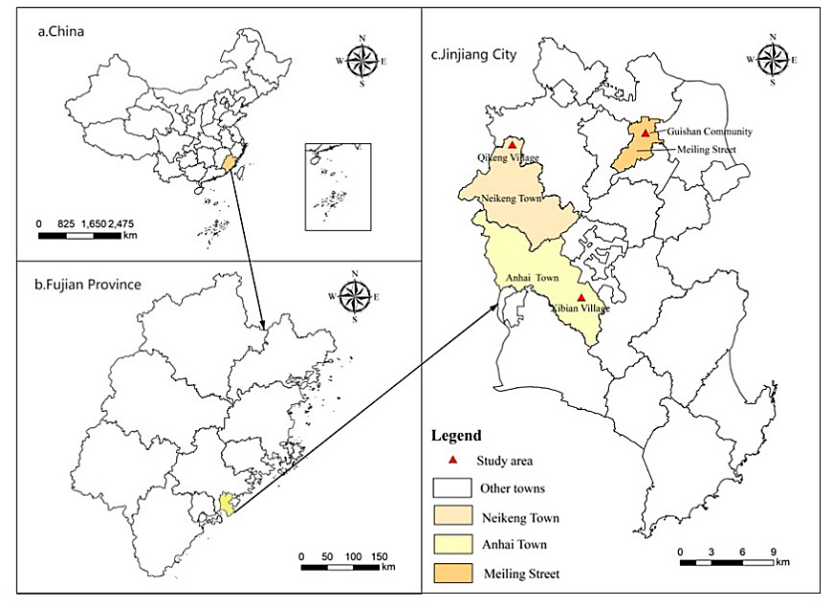

Figure 2. Three empirical areas

family economy, and other related information in the study area to understand the changes in the livelihoods of farmers after HW in detail. Then, data were collected via random sampling from farmers using interview questionnaires. After data sorting and statistical analysis, 31 invalid samples with incomplete and inconsistent information were eliminated. A total of 367 valid questionnaires were collected, with an effective rate of $92.21 \%$. The G community in the asset replacement model accounted for $33.79 \%$, the $\mathrm{Q}$ village in the index replacement model accounted for $33.51 \%$, and the $\mathrm{X}$ village in the monetary compensation model accounted for $32.70 \%$ of the data.

\subsection{Empirical variables}

Existing research that explored the factors influencing HW provides a strong reference for the selection of empirical variables for this study. Table 1 shows the definition and assignment of specific variables in this study.

\subsubsection{Dependent variable}

The dependent variable, HW, indicated whether farmers were willing to choose this mode to withdraw, where " 1 = willing, 0 = unwilling".

\subsubsection{Control variables}

According to existing research results (Sun et al., 2018; Liu et al., 2020; Yang et al., 2021), three variables, namely, gender $\left(X_{1}\right)$, age $\left(X_{2}\right)$, and population size $\left(X_{3}\right)$, were selected as control variables to reflect the individual characteristics of farmers. The reason is that gender and age affect the employment skills and income sources of farmers, which in turn affects their production and lifestyles when they quit their homesteads. Chinese farmers have a natural emotional dependence on land, especially among the older generation of farmers who lived before the implementation of the reform and liberalization policies in 1978 (Yang et al., 2021). Sun et al. (2018) also observed that older farmers will become more dependent on land, because their chances of working in cities are smaller, and therefore, they are less willing to leave HW. In addition, gender is also regarded as a key control variable, as Liu et al. (2020) included this factor in as the critical factor to impact the HW. The

Table 1. Variable definition and descriptive statistics

\begin{tabular}{|c|c|c|c|c|}
\hline & Variables & Definition & Mean & Std. \\
\hline \multicolumn{5}{|c|}{ Dependent variable } \\
\hline & HW & $1=$ Yes; $0=$ No & 0.563 & 0.122 \\
\hline \multicolumn{5}{|c|}{ Independent variable } \\
\hline \multirow{3}{*}{ 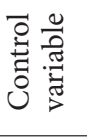 } & Gender $\left(X_{1}\right)$ & Man $=1 ;$ Female $=0$ & 0.73 & 1.233 \\
\hline & Age $\left(X_{2}\right)$ & $1=\leq 30 ; 2=31 \sim 40 ; 3=41 \sim 50 ; 4=51 \sim 60 ; 5=>60$ & 3.57 & 1.010 \\
\hline & Household size $\left(X_{3}\right)$ & Number of households & 3.78 & 1.232 \\
\hline \multirow{2}{*}{ 吾尝 } & Cultivated area $\left(X_{4}\right)$ & $\begin{array}{l}1=<0.5 \mathrm{mu} ; 2=0.5 \sim 1 \mathrm{mu} ; 3=1 \sim 1.5 \mathrm{mu} ; 4=1.5 \sim 2 \mathrm{mu} \\
5=>2.1 \mathrm{mu}\end{array}$ & 0.781 & 1.216 \\
\hline & Homestead area $\left(X_{5}\right)$ & $\begin{array}{l}1=\text { Below } 100 \mathrm{~m}^{2} ; 2=100 \sim 150 \mathrm{~m}^{2} ; 3=150 \sim 200 \mathrm{~m}^{2} \\
4=200 \sim 250 \mathrm{~m}^{2} ; 5=\text { Above } 250 \mathrm{~m}^{2}\end{array}$ & 3.89 & 1.754 \\
\hline \multirow{2}{*}{ 营 } & Household income $\left(X_{6}\right)$ & $1=<5 ; 2=5-10 ; 3=10-15 ; 4=15-20 ; 5=>20$ & 3.43 & 1.248 \\
\hline & Household income type $\left(X_{7}\right)$ & $\begin{array}{l}1=\text { pure agricultural } ; 2=\text { agricultural part-time; } \\
3=\text { non-agricultural part-time } 4=\text { non-agricultural }\end{array}$ & 3.89 & 1.010 \\
\hline 㲎蔦 & Highest level of education $\left(X_{8}\right)$ & $\begin{array}{l}1=\text { below elementary school; } 2=\text { primary school; } \\
3=\text { junior high school; } 4=\text { high school or technical } \\
\text { secondary school; } 5 \text { = junior college and above }\end{array}$ & 3.56 & 1.024 \\
\hline \multirow{4}{*}{ 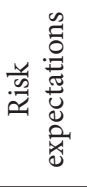 } & Life condition $\left(X_{9}\right)$ & \multirow{4}{*}{$\begin{array}{l}1=\text { a lot better; } 2=\text { a little better; } 3=\text { the same; } \\
4=\text { a little worse; } 5=\text { a lot worse }\end{array}$} & 2.56 & 1.580 \\
\hline & Social security $\left(X_{10}\right)$ & & 3.12 & 1.029 \\
\hline & Residential environment $\left(X_{11}\right)$ & & 2.11 & 1.167 \\
\hline & Psychological condition $\left(X_{12}\right)$ & & 2.37 & 1.524 \\
\hline
\end{tabular}


household size mainly affects whether farmers are willing to choose the corresponding mode to HW and the allocation of family assets. Larger population size sizes can lead to a heavy economic burden when living in cities, which means that it may inhibit farmers' HW behavior (Sun et al., 2018).

\subsubsection{Key variables for livelihoods}

For the independent variables of livelihoods, (1) natural capital was represented by cultivated area $\left(X_{4}\right)$ and homestead area $\left(X_{5}\right)$ as empirical variables (Li et al., 2020); (2) financial capital was represented by household income $\left(X_{6}\right)$ and household income type $\left(X_{7}\right)$ (Sun et al., 2018; Kuang et al., 2020; Li et al., 2020; Xiao et al., 2020; Yan et al., 2021); and (3) human capital was represented by the farmer's highest level of education $\left(X_{8}\right)$ (Li et al., 2020; Kuang et al., 2020; Yang et al., 2021).

\subsubsection{Key variables for risk expectation}

In terms of empirical variables for risk expectation, based on the micro-welfare perspective of farmers, this study used the theory of capability approach proposed by Sen (1999). Moreover, the study clarified farmers' rights in terms of freedom of decision-making and participation, economic conditions, social opportunities, transparency guarantees, and protective guarantees (Liang \& Lin, 2019; Zhu \& Cai, 2016). This study used a 5-point Likert scale to measure the expected risks from four aspects, namely, life condition $\left(X_{9}\right)$, social security $\left(X_{10}\right)$, residential environment $\left(X_{11}\right)$, and psychological conditions $\left(X_{12}\right)$.

\subsection{Empirical model}

Whether farmers are willing to choose this HW mode is a binary choice variable. The binary probit model is a virtual explained variable model estimation method that uses the deformation of the cumulative normal distribution function to avoid the unbounded problem of linear probability models (Liu et al., 2019). This model is mainly used when the dependent variable is a binary choice; precisely, 0 or 1 is selected for the dependent variable. Related farmer behavior research also used this method (Sun et al., 2018; Liu et al., 2020; Yang et al., 2021). The basic form of the probit model used in this study was as follows:

$$
Y=\beta_{0}+\beta_{1} X_{1}+\beta_{2} X_{2}+\cdots+\beta_{12} X_{12}+\mu,
$$

where: $Y$ is the dependent variable representing the farmers' willingness to choose (unwilling $=0$, willing $=1$ ); $\beta_{0}$ is a constant term; $X_{1}, X_{2} \ldots, X_{12}$ are the independent variables; $\beta_{1}, \beta_{2} \ldots, \beta_{12}$ represent the independent variable coefficients, such as livelihood capital and risk expectations; $\mu$ is random disturbance terms, which affect the willingness for HW. The binary discrete choice model can be expressed as follows:

$$
\begin{aligned}
& P_{i}=E\left(Y=0 / X_{1}, X_{2}, \ldots, X_{12}\right)= \\
& F\left(\beta_{0}+\beta_{1} X_{1}+\beta_{2} X_{2}+\ldots+\beta_{12} X_{12}+\mu\right),
\end{aligned}
$$

where: $P_{i}$ is the probability that a farmer makes a certain choice under certain influencing conditions; $E(X)$ is a certain factor that influences the choice. Under the mathematical expectation for this choice under certain conditions, $F(X)$ is a cumulative probability distribution function of $1 / \sqrt{2 \pi}=\int_{\infty}^{I_{i}} e^{-t^{2} / 2} d t$.

\section{Results}

\subsection{Related pre-test}

Stata 11.0 statistical software is used in all empirical procedures. Before formally conducting the probit model analysis, whether the high correlation between farmers' livelihoods and risk expectations will lead to multicollinearity problems was first confirmed. It is generally believed that multicollinearity exists when $0<$ variance inflation factor $(\mathrm{VIF})<10$. The multicollinearity test was performed on all variables of the three models, and the results showed that no serious collinearity problem exists among the explanatory variables (Table 2 ). This finding shows that eliminating

Table 2. Multicollinearity test results of HW pattern intention

\begin{tabular}{|l|c|c|c|c|c|c|}
\hline \multirow{2}{*}{\multicolumn{2}{c|}{ Variables }} & \multicolumn{2}{|c|}{ Asset replacement model } & \multicolumn{2}{c|}{ Index replacement model } & \multicolumn{2}{c|}{$\begin{array}{c}\text { Monetary compensation } \\
\text { model }\end{array}$} \\
\cline { 2 - 7 } & VIF & $1 /$ VIF & VIF & $1 /$ VIF & VIF & $1 /$ VIF \\
\hline Gender $\left(X_{1}\right)$ & 1.3 & 0.77 & 2.79 & 0.36 & 2.81 & 0.36 \\
\hline Age $\left(X_{2}\right)$ & 1.69 & 0.59 & 5.98 & 0.17 & 6.22 & 0.16 \\
\hline Population size $\left(X_{3}\right)$ & 2.25 & 0.44 & 1.07 & 0.93 & 7.53 & 0.13 \\
\hline Cultivated area $\left(X_{4}\right)$ & 1.21 & 0.83 & 1.15 & 0.87 & 2.04 & 0.49 \\
\hline Homestead area $\left(X_{5}\right)$ & 1.48 & 0.68 & 1.55 & 0.65 & 1.95 & 0.51 \\
\hline Household income $\left(X_{6}\right)$ & 1.66 & 0.60 & 2.20 & 0.45 & 2.35 & 0.43 \\
\hline Household income type $\left(X_{7}\right)$ & 1.17 & 0.86 & 2.94 & 0.34 & 3.31 & 0.3 \\
\hline Highest level of education $\left(X_{8}\right)$ & 1.42 & 0.70 & 1.06 & 0.95 & 1.12 & 0.89 \\
\hline Life condition $\left(X_{9}\right)$ & 1.43 & 0.70 & 6.73 & 0.15 & 1.14 & 0.88 \\
\hline Social security $\left(X_{10}\right)$ & 1.19 & 0.84 & 1.17 & 0.86 & 1.14 & 0.87 \\
\hline Residential environment $\left(X_{11}\right)$ & 1.53 & 0.65 & 1.03 & 0.97 & 1.06 & 0.94 \\
\hline Psychological condition $\left(X_{12}\right)$ & 1.22 & 0.82 & 2.41 & 0.41 & 1.17 & 0.86 \\
\hline
\end{tabular}


Table 3. Breusch-Pagan test for heterogeneous detection

\begin{tabular}{|l|c|c|}
\hline & $\chi^{2}$ & $p$ \\
\hline Pooled model & 20.413 & 0.060 \\
\hline Asset replacement model & 103.593 & 0.138 \\
\hline Index replacement model & 93.512 & 0.224 \\
\hline Monetary compensation model & 83.942 & 0.331 \\
\hline
\end{tabular}

or adjusting independent variables is not necessary, thereby providing a prerequisite for the regression analysis of the next model. In addition, the Breusch-Pagan test (Breusch \& Pagan, 1979) revealed that the pooled and individual three models had no problem of heteroscedasticity (Table 3 ).

In this study, considering the three variables, namely, cultivated area $\left(X_{4}\right)$, homestead area $\left(X_{5}\right)$, and household income $\left(X_{6}\right)$, a reverse causal relationship with a dependent variable may exist, that is, there may be potential endogenous problems. To solve this problem, following relevant literature practices (Sun \& Zhao, 2020), selecting the "average cultivated area in the same community outside the sample itself", "average homestead area in the same community outside the sample itself", and "average household income in the same community outside the sample itself" as instrumental variables were combined with Durbin (Durbin, 1954). Wu-Hausman tests (Wu, 1973, 1974; Hausman, 1978) confirm the problem of endogeneity. The basis for the selection of instrumental variables is that instrumental variables are relevant. The abovementioned instrumental variables can reflect the overall level of livelihood capital and are closely related to the level of farmers' livelihood capital. From another aspect, the instrumental variables are exogenous, and no connection is found between the instrumental variables after excluding individual information and their HW behavior. The result indicates that the pooled model and the three individual models reject the null hypothesis (Table 4), that is, there is no endogenous problem among variables. Therefore, it can be concluded that the results presented in this study are convincing.

\subsection{Result of pooled model}

Table 5 shows the results of the pooled model. (1) In terms of the control variable, gender and population size have insignificant impacts on HW, whereas age has a significant negative impact on HW. (2) In terms of livelihood capital, cultivated area $\left(X_{4}\right)$ and the homestead area $\left(X_{5}\right)$ in natural capital have a significant negative impact on $\mathrm{HW}$. Household income $\left(X_{6}\right)$ in financial capital has insignificant impact on HW, whereas the household income type $\left(X_{7}\right)$ has a significant positive impact on HW. The highest level of education $\left(X_{8}\right)$ in terms of human capital has a positive but insignificant impact on HW. (3) Regarding risk expectations, the risk expectations of life condition $\left(X_{9}\right)$ have a negative but not significant impact on HW. However, risk expectations such as social security $\left(X_{10}\right)$, residential environment $\left(X_{11}\right)$, and psychological condition $\left(X_{12}\right)$ have a significant negative impact on HW.

Table 4. Durbin and $\mathrm{Wu}-$ Hausman test for endogenous detection

\begin{tabular}{|l|l|c|}
\hline & \multicolumn{1}{|c|}{ Test } & \multicolumn{1}{c|}{ Result } \\
\hline \multirow{2}{*}{ Pooled model } & Durbin test & $\chi^{2}(3)=9.147, p=0.027$ \\
\cline { 2 - 3 } & Wu-Hausman test & $F(3,351)=2.991, p=0.031$ \\
\hline \multirow{2}{*}{ Asset replacement model } & Durbin test & $\chi^{2}(3)=1.547, p=0.671$ \\
\cline { 2 - 3 } & Wu-Hausman test & $F(3,108)=0.455, p=0.714$ \\
\hline Index replacement model & Durbin test & $\chi^{2}(3)=6.678, p=0.083$ \\
\cline { 2 - 3 } & Wu-Hausman test & $F(3,107)=2.048, p=0.112$ \\
\hline \multirow{2}{*}{ Monetary compensation model } & Durbin test & $\chi^{2}(3)=4.450, p=0.217$ \\
\cline { 2 - 3 } & Wu-Hausman test & $F(3,104)=1.335, p=0.267$ \\
\hline
\end{tabular}

Table 5. Result of pooled model

\begin{tabular}{|c|c|c|c|}
\hline & Variables & All of sample & Eliminate extreme sample \\
\hline \multirow[t]{3}{*}{ Control variable } & Gender $\left(X_{1}\right)$ & $\begin{array}{c}0.265 \\
(1.435)\end{array}$ & $\begin{array}{c}0.139 \\
(0.592)\end{array}$ \\
\hline & Age $\left(X_{2}\right)$ & $\begin{array}{c}-0.838^{\star * *} \\
(-8.574)\end{array}$ & $\begin{array}{c}-0.912^{\star * *} \\
(-8.150)\end{array}$ \\
\hline & Population size $\left(X_{3}\right)$ & $\begin{array}{c}0.097 \\
(1.096)\end{array}$ & $\begin{array}{c}0.071 \\
(0.729)\end{array}$ \\
\hline \multirow[t]{2}{*}{ Natural capital } & Cultivated area $\left(X_{4}\right)$ & $\begin{array}{l}-0.128^{\star} \\
(-1.852)\end{array}$ & $\begin{array}{c}-0.122 \\
(-1.562)\end{array}$ \\
\hline & Homestead area $\left(X_{5}\right)$ & $\begin{array}{l}-0.322^{\star * *} \\
(-3.229)\end{array}$ & $\begin{array}{c}-0.304^{\star * \star} \\
(-2.704)\end{array}$ \\
\hline
\end{tabular}


End of Table 5

\begin{tabular}{|c|c|c|c|}
\hline & Variables & All of sample & Eliminate extreme sample \\
\hline \multirow[t]{2}{*}{ Financial capital } & Household income $\left(X_{6}\right)$ & $\begin{array}{c}0.067 \\
(0.753)\end{array}$ & $\begin{array}{c}0.372^{\star * *} \\
(2.809)\end{array}$ \\
\hline & Household income type $\left(X_{7}\right)$ & $\begin{array}{c}0.236^{\star * *} \\
(2.585)\end{array}$ & $\begin{array}{c}0.298^{\star * *} \\
(2.826)\end{array}$ \\
\hline Human capital & Highest level of education $\left(X_{8}\right)$ & $\begin{array}{c}0.127 \\
(1.570)\end{array}$ & $\begin{array}{c}0.148^{\star} \\
(1.686)\end{array}$ \\
\hline \multirow[t]{4}{*}{ Risk expectations } & Life condition $\left(X_{9}\right)$ & $\begin{array}{c}-0.012 \\
(0.143)\end{array}$ & $\begin{array}{c}-0.048 \\
(-0.519) \\
\end{array}$ \\
\hline & Social security $\left(X_{10}\right)$ & $\begin{array}{c}-0.184^{\star * \star} \\
(-2.657)\end{array}$ & $\begin{array}{c}-0.215^{\star \star \star} \\
(-2.841)\end{array}$ \\
\hline & Residential environment $\left(X_{11}\right)$ & $\begin{array}{c}-0.288^{\star * \star} \\
(-3.298)\end{array}$ & $\begin{array}{c}-0.293^{\star * *} \\
(-3.154)\end{array}$ \\
\hline & Psychological condition $\left(X_{12}\right)$ & $\begin{array}{c}-0.403^{\star * *} \\
(-4.650)\end{array}$ & $\begin{array}{c}-0.459^{* * *} \\
(-4.650)\end{array}$ \\
\hline \multicolumn{2}{|l|}{ Constant } & $\begin{array}{c}5.284^{* * *} \\
(5.642)\end{array}$ & $\begin{array}{c}5.086^{* * *} \\
(4.919)\end{array}$ \\
\hline \multicolumn{2}{|l|}{ Log likelihood } & 141.520 & 146.260 \\
\hline \multicolumn{2}{|l|}{ Prob > chi2 } & 0.007 & 0.020 \\
\hline \multicolumn{2}{|l|}{$N$} & 367 & 331 \\
\hline
\end{tabular}

Notes: Standard errors are indicated in parentheses. ${ }^{*}$ indicates $p<0.1$; ${ }^{* *}$ indicates $p<0.05 ;{ }^{* *}$ indicates $p<0.01$.

\subsection{Result of the three individual models}

Table 6 and Figure 3 present the results of three individual models. (1) The control variables implied by household characteristics are indicated. Gender $\left(X_{1}\right)$ has insignificant negative impacts on $\mathrm{HW}$ under the three models. Age $\left(X_{2}\right)$ also has significant negative impacts on the three models. Moreover, the population size variable $\left(X_{3}\right)$ has a significant positive impact on HW under the asset replacement model. However, this variable has significant negative impacts on HW under the index replacement and monetary compensation models. (2) Regarding the empirical aspect of the livelihood dimension, the cultivated area $\left(X_{4}\right)$ has insignificant impact on HW under the asset replacement model but has significant negative impacts on the index replacement and monetary compensation models. The homestead area $\left(X_{5}\right)$ has significant negative impacts on all the three models. Household income $\left(X_{6}\right)$, which represented financial capital, has a significant positive impact on $\mathrm{HW}$ under the asset replacement model. However, household income has significant negative impacts on $\mathrm{HW}$ under the index replacement and monetary compensation models. The household income type $\left(X_{7}\right)$ has significant positive impacts on HW under the asset replacement and monetary compensation models, whereas the index replacement model reveals a significant negative impact on $\mathrm{HW}$. The highest level of education $\left(X_{8}\right)$ has significant negative and positive impacts on HW under the asset replacement mod$\mathrm{el}$, and the index replacement and monetary compensation models, respectively. (3) Regarding the dimension of risk expectation, the life condition $\left(X_{9}\right)$ under the asset replacement and index replacement models has a positive but not significant impact on HW and only a significant negative impact on HW under the monetary compensation model. Further, the social security $\left(X_{10}\right)$ and residential environment $\left(X_{11}\right)$ under the three models have a significant negative impact on HW. In terms of psychological conditions $\left(X_{12}\right)$, only the asset replacement and monetary compensation models reveal a significant negative impact, whereas the index replacement model reveals a positive impact on HW, which was not significant.

Table 6. Results of individual models

\begin{tabular}{|c|c|c|c|c|c|c|c|}
\hline & \multirow{2}{*}{ Variables } & \multicolumn{2}{|c|}{ Asset replacement model } & \multicolumn{2}{|c|}{ Index replacement model } & \multicolumn{2}{|c|}{$\begin{array}{l}\text { Monetary compensation } \\
\text { model }\end{array}$} \\
\hline & & All of sample & $\begin{array}{c}\text { Eliminate } \\
\text { extreme sample }\end{array}$ & All of sample & $\begin{array}{c}\text { Eliminate } \\
\text { extreme sample }\end{array}$ & All of sample & $\begin{array}{c}\text { Eliminate } \\
\text { extreme sample }\end{array}$ \\
\hline \multirow{3}{*}{ 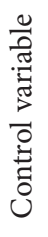 } & Gender $\left(X_{1}\right)$ & $\begin{array}{l}-0.169 \\
(-0.257)\end{array}$ & $\begin{array}{c}0.333 \\
(0.395)\end{array}$ & $\begin{array}{c}0.126 \\
(0.103)\end{array}$ & $\begin{array}{l}-0.902 \\
(-0.676)\end{array}$ & $\begin{array}{l}-1.483 \\
(-1.472)\end{array}$ & $\begin{array}{l}-2.403^{\star} \\
(-1.813)\end{array}$ \\
\hline & Age $\left(X_{2}\right)$ & $\begin{array}{c}-3.192^{\star * *} \\
(-3.698)\end{array}$ & $\begin{array}{c}-5.719^{\star * *} \\
(-2.880)\end{array}$ & $\begin{array}{l}-1.145^{\star * *} \\
(-2.994)\end{array}$ & $\begin{array}{c}-1.199^{\star * *} \\
(-3.078)\end{array}$ & $\begin{array}{c}-1.317^{\star * *} \\
(-2.669)\end{array}$ & $\begin{array}{l}-1.295^{\star *} \\
(-2.567)\end{array}$ \\
\hline & Population size $\left(X_{3}\right)$ & $\begin{array}{l}2.044^{* * *} \\
(2.964)\end{array}$ & $\begin{array}{l}2.972^{* * *} \\
(2.642)\end{array}$ & $\begin{array}{l}-0.525^{\star *} \\
(-2.423)\end{array}$ & $\begin{array}{l}-0.529^{\star *} \\
(-2.422)\end{array}$ & $\begin{array}{l}-1.486^{\star *} \\
(-2.040)\end{array}$ & $\begin{array}{l}-1.166 \\
(-1.538)\end{array}$ \\
\hline
\end{tabular}


End of Table 6

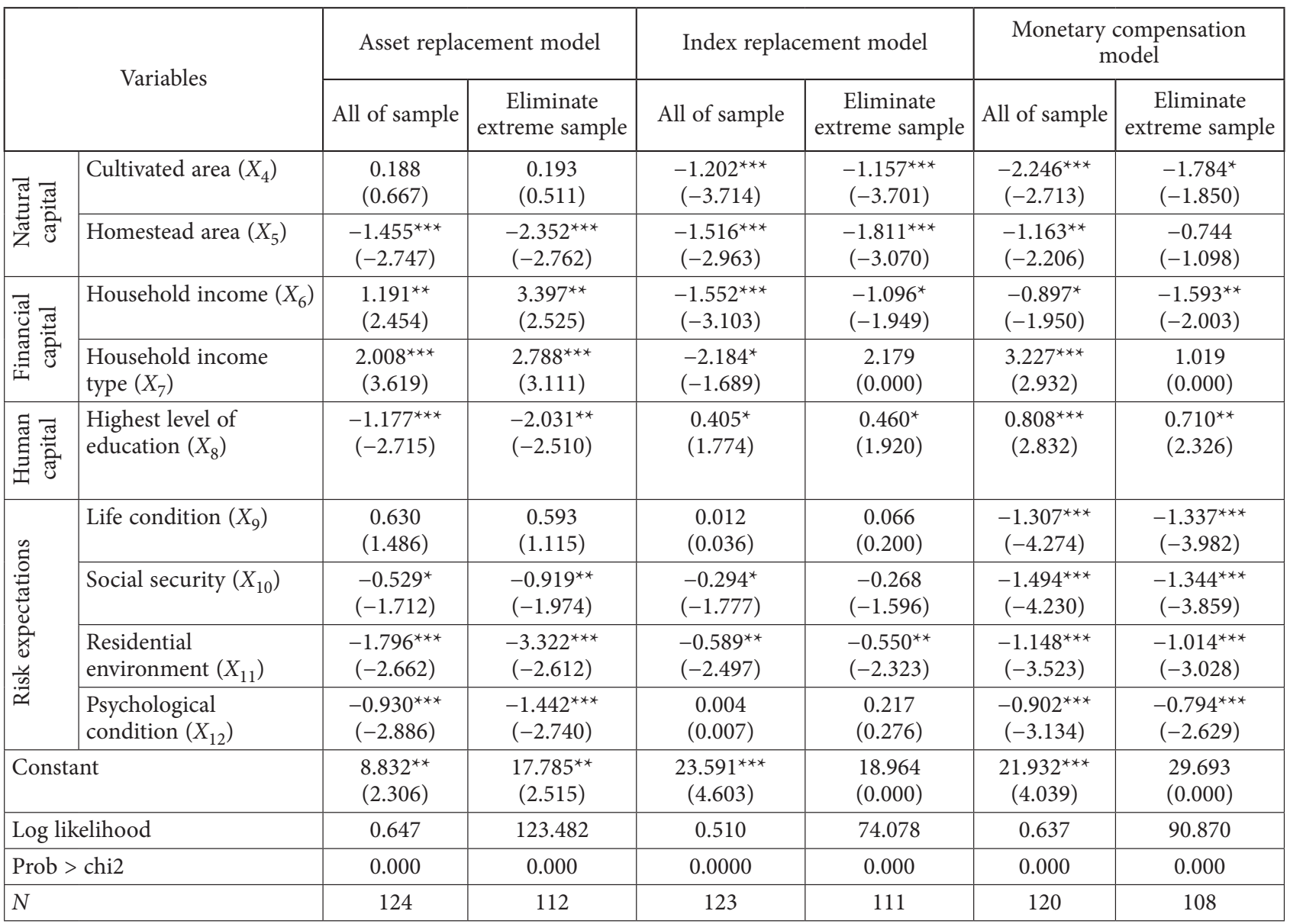

Notes: Standard errors are indicated in parentheses. ${ }^{*}$ indicates $p<0.1 ;{ }^{* *}$ indicates $p<0.05$; ${ }^{* *}$ indicates $p<0.01$.

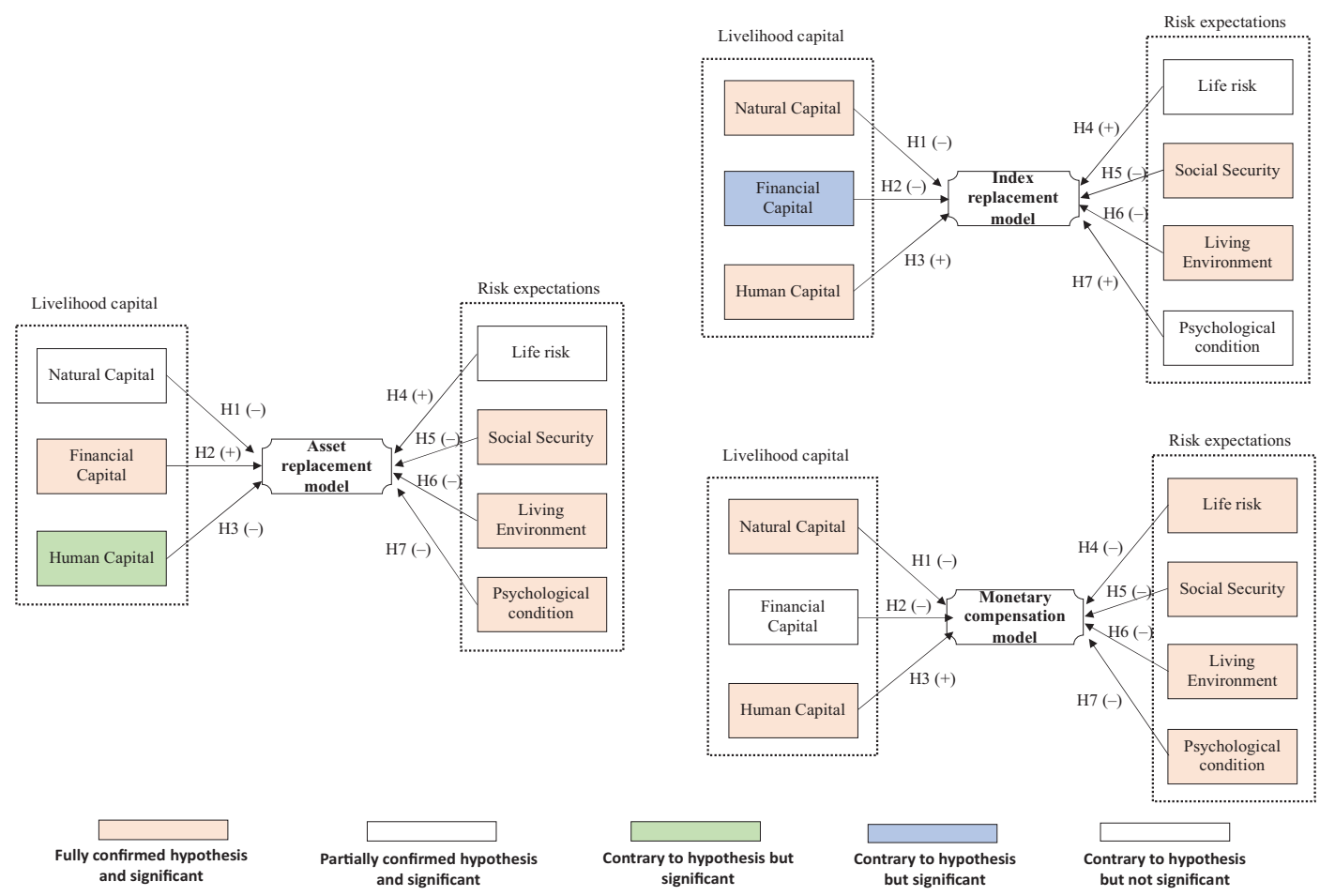

Figure 3. Empirical result for three individual models 


\subsection{Result of heterogeneity sources}

In order to further examine the sources of heterogeneity on HW, this study regresses the interaction impact of HW on livelihoods capital $\left(X_{4}\right.$ to $\left.X_{8}\right)$ or risk expectations $\left(X_{9}\right.$ to $X_{12}$ ) variables with gender $\left(X_{1}\right)$, age $\left(X_{2}\right)$ and population size $\left(X_{3}\right)$ representing the household heterogeneity. Table 7 for the results indicate age $\left(X_{2}\right) \times$ cultivated area $\left(X_{4}\right)$, gender $\left(X_{1}\right) \times$ household income $\left(X_{6}\right)$, population size $\left(X_{3}\right) \times$ household income type $\left(X_{7}\right)$, gender $\left(X_{1}\right) \times$ highest level of education $\left(X_{8}\right)$, and age $\left(X_{2}\right) \times$ psychological condition $\left(X_{12}\right)$ has the significant impact on HW. It can be analyzed as follows: (1) Age is the important source of the heterogeneity of cultivated land area to impact the HW, which means that the older farmers and the larger the cultivated area, the more willing to HW. This is because the older farmers are limited engaged in agricultural production, middle-aged farmers are more willing to develop the relevant agricultural production. (2) The interaction between gender and household income has a positively significant impact on HW, that is, male households with higher income are more willing to HW. It can be explained by that male farmers are often adventurous and able to take risks, compared with female households. At the same time, male farmers with a high income will be more inclined to tap the asset attributes of homesteads, thereby realizing the appreciation of assets. (3) Population size is an explanatory heterogeneous source of household income types to impact the HW. The larger the population size with the more non-agricultural income are willing to HW. This type of households generally have a higher degree of occupational differentiation and a diversified family income structure. Therefore, the ability to diversify and avoid risks is stronger. (4) The interaction between gender and the highest level of education have significant positive impact on HW. Gender is as the important source of heterogeneity on highest level of education to impact the HW. The men farmers with higher the level of education are more willing to HW. It echoes to the previous viewpoints that male farmers have often more adventurous spirit to decision-making their assists under the condition of abundant resource endowments. (5) The interaction between age and psychological conditions have significantly negative impact on HW. Older farmers have less effective in mediating psychological conditions after HW than younger farmers. This can be explained by older people have usually weaker psychological adaptation ability to resist risks.

\subsection{Result of interaction impact}

To further explore the interaction impact between livelihood capital and risk expectation on the HW, this paper conducts an empirical study on the interaction of the two variables. Table 8 shows the empirical results. (1) The interaction between cultivated area $\left(X_{4}\right)$ and life condition $\left(X_{9}\right)$ has a significant positive impact on HW. Thus, the risk of living conditions is expected to alleviate the

Table 7. Heterogeneity check

\begin{tabular}{|c|c|c|c|c|c|}
\hline & Variables & All of sample & & Variables & All of sample \\
\hline \multirow[t]{3}{*}{ Control variable } & $X_{1}$ & $-2.278(-0.963)$ & \multirow{3}{*}{$\begin{array}{l}\text { Household income } \\
\text { type } \times \text { Control variable }\end{array}$} & $X_{7} \times X_{1}$ & $-0.067(-0.259)$ \\
\hline & $X_{2}$ & $-0.629(-0.582)$ & & $X_{7} \times X_{2}$ & $-0.171(-1.372)$ \\
\hline & $X_{3}$ & $0.748(0.677)$ & & $X_{7} \times X_{3}$ & $0.406^{\star \star}(2.626)$ \\
\hline \multirow[t]{2}{*}{ Natural capital } & $X_{4}$ & $-1.079^{\star \star}(-2.631)$ & \multirow{3}{*}{$\begin{array}{l}\text { Highest level of } \\
\text { education } \times \\
\text { Control variable }\end{array}$} & $X_{8} \times X_{1}$ & $0.459^{*}(1.969)$ \\
\hline & $X_{5}$ & $-0.431(-0.943)$ & & $X_{8} \times X_{2}$ & $-0.106(-0.762)$ \\
\hline \multirow[t]{2}{*}{ Financial capital } & $X_{6}$ & $-0.560(-0.849)$ & & $X_{8} \times X_{3}$ & $-0.033(-0.272)$ \\
\hline & $X_{7}$ & $-0.424(-0.786)$ & \multirow{3}{*}{$\begin{array}{l}\text { Life condition } \times \\
\text { Control variable }\end{array}$} & $X_{9} \times X_{1}$ & $-0.132(-0.533)$ \\
\hline Human capital & $X_{8}$ & $0.310(0.511)$ & & $X_{9} \times X_{2}$ & $-0.088(-0.914)$ \\
\hline \multirow[t]{4}{*}{ Risk expectations } & $X_{9}$ & $0.642(1.330)$ & & $X_{9} \times X_{3}$ & $-0.087(-0.797)$ \\
\hline & $X_{10}$ & $0.246(0.481)$ & \multirow{3}{*}{$\begin{array}{l}\text { Social security } \times \\
\text { Control variable }\end{array}$} & $X_{10} \times X_{1}$ & $-0.215(-1.060)$ \\
\hline & $X_{11}$ & $0.313(0.612)$ & & $X_{10} \times X_{2}$ & $-0.019(-0.197)$ \\
\hline & $X_{12}$ & $-0.243(-0.464)$ & & $X_{10} \times X_{3}$ & $-0.078(-0.742)$ \\
\hline \multirow{3}{*}{$\begin{array}{l}\text { Cultivated } \\
\text { area } \times \text { Control } \\
\text { variable }\end{array}$} & $X_{4} \times X_{1}$ & $-0.243(-1.375)$ & \multirow{3}{*}{$\begin{array}{l}\text { Residential } \\
\text { environment } \times \\
\text { Control variable }\end{array}$} & $X_{11} \times X_{1}$ & $0.166(0.550)$ \\
\hline & $X_{4} \times X_{2}$ & $0.259^{* *}(2.680)$ & & $X_{11} \times X_{2}$ & $-0.044(-0.286)$ \\
\hline & $X_{4} \times X_{3}$ & $0.035(0.360)$ & & $X_{11} \times X_{3}$ & $-0.217(-1.441)$ \\
\hline \multirow{3}{*}{$\begin{array}{l}\text { Homestead } \\
\text { area } \times \text { Control } \\
\text { variable }\end{array}$} & $X_{5} \times X_{1}$ & $0.049(0.161)$ & \multirow{3}{*}{$\begin{array}{l}\text { Psychological } \\
\text { condition } \times \text { Control } \\
\text { variable }\end{array}$} & $X_{12} \times X_{1}$ & $0.197(0.888)$ \\
\hline & $X_{5} \times X_{2}$ & $0.005(0.043)$ & & $X_{12} \times X_{2}$ & $-0.237^{\star}(-2.134)$ \\
\hline & $X_{5} \times X_{3}$ & $-0.046(-0.402)$ & & $X_{12} \times X_{3}$ & $0.106(0.768)$ \\
\hline \multirow{3}{*}{$\begin{array}{l}\text { Household } \\
\text { income } \times \text { Control } \\
\text { variable }\end{array}$} & $X_{6} \times X_{1}$ & $0.627^{\star}(2.391)$ & \multicolumn{2}{|c|}{ Constant } & $5.722(1.110)$ \\
\hline & $X_{6} \times X_{2}$ & $0.168(1.141)$ & \multicolumn{2}{|c|}{ Log likelihood } & 208.733 \\
\hline & $X_{6} \times X_{3}$ & $-0.089(-0.605)$ & \multicolumn{2}{|c|}{ Prob > chi2 } & 0.287 \\
\hline
\end{tabular}

Notes: Standard errors are indicated in parentheses. ${ }^{*}$ indicates $p<0.1$; ${ }^{* *}$ indicates $p<0.05$; ${ }^{* *}$ indicates $p<0.01$. 
Table 8. Results of the interaction model for the pooled model

\begin{tabular}{|c|c|c|c|}
\hline & Variables & All of sample & Eliminate extreme sample \\
\hline \multirow[t]{3}{*}{ Control variable } & Gender $\left(X_{1}\right)$ & $0.161(0.773)$ & $-0.090(-0.350)$ \\
\hline & Age $\left(X_{2}\right)$ & $-0.960^{\star * \star}(-8.322)$ & $-0.993^{\star \star \star}(-7.828)$ \\
\hline & Population size $\left(X_{3}\right)$ & $0.032(0.330)$ & $0.051(0.485)$ \\
\hline \multirow[t]{8}{*}{ Natural capital $\times$ Risk expectation } & $X_{4} \times X_{9}$ & $0.094^{\star}(1.736)$ & $0.101^{\star}(1.717)$ \\
\hline & $X_{4} \times X_{10}$ & $0.040(0.833)$ & $0.018(0.353)$ \\
\hline & $X_{4} \times X_{11}$ & $-0.083^{\star}(-1.684)$ & $-0.085(-1.623)$ \\
\hline & $X_{4} \times X_{12}$ & $-0.133^{\star * \star}(-3.218)$ & $-0.125^{\star \star \star}(-2.843)$ \\
\hline & $X_{5} \times X_{9}$ & $-0.108(-1.590)$ & $-0.111(-1.479)$ \\
\hline & $X_{5} \times X_{10}$ & $-0.068(-1.038)$ & $-0.113(-1.545)$ \\
\hline & $X_{5} \times X_{11}$ & $0.002(0.021)$ & $-0.008(-0.090)$ \\
\hline & $X_{5} \times X_{12}$ & $-0.004(-0.067)$ & $0.048(0.724)$ \\
\hline \multirow[t]{8}{*}{ Financial capital $\times$ Risk expectation } & $X_{6} \times X_{9}$ & $-0.009(-0.110)$ & $0.035(0.314)$ \\
\hline & $X_{6} \times X_{10}$ & $0.010(0.128)$ & $0.098(1.032)$ \\
\hline & $X_{6} \times X_{11}$ & $-0.179^{\star \star}(-2.061)$ & $-0.195^{\star}(-1.885)$ \\
\hline & $X_{6} \times X_{12}$ & $0.244^{\star * *}(3.441)$ & $0.154^{*}(1.846)$ \\
\hline & $X_{7} \times X_{9}$ & $-0.054(-0.883)$ & $-0.032(-0.490)$ \\
\hline & $X_{7} \times X_{10}$ & $-0.050(-1.001)$ & $-0.057(-1.112)$ \\
\hline & $X_{7} \times X_{11}$ & $0.080(1.420)$ & $0.070(1.189)$ \\
\hline & $X_{7} \times X_{12}$ & $0.056(1.046)$ & $0.044(0.775)$ \\
\hline \multirow[t]{4}{*}{ Human capital $\times$ Risk expectation } & $X_{8} \times X_{9}$ & $0.092(1.250)$ & $0.023(0.285)$ \\
\hline & $X_{8} \times X_{10}$ & $-0.006(-0.079)$ & $-0.019(-0.243)$ \\
\hline & $X_{8} \times X_{11}$ & $0.106(1.435)^{\star}$ & $0.154^{\star \star}(1.992)$ \\
\hline & $X_{8} \times X_{12}$ & $-0.234^{\star * \star}(-3.781)$ & $-0.201^{\star \star \star}(-3.096)$ \\
\hline \multicolumn{2}{|l|}{ Constant } & $4.993^{* \star \star}(7.444)$ & $5.251^{\star \star \star}(7.321)$ \\
\hline \multicolumn{2}{|l|}{ Log likelihood } & 178.188 & 160.875 \\
\hline \multicolumn{2}{|l|}{ Prob > chi2 } & 0.000 & 0.000 \\
\hline \multicolumn{2}{|l|}{$N$} & 367 & 331 \\
\hline
\end{tabular}

Notes: Standard errors are indicated in parentheses. ${ }^{*}$ indicates $p<0.1$; ${ }^{* *}$ indicates $p<0.05$; ${ }^{* *}$ indicates $p<0.01$.

negative impact of natural capital on HW. On the contrary, the negative interaction impact on the residential environment $\left(X_{11}\right)$ or psychological conditions $\left(X_{11}\right)$ and cultivated area $\left(X_{4}\right)$ implies that the risk factors of living and psychological conditions have further strengthened the inhibitory effect of natural capital on HW. (2) The negative interaction impact between household income $\left(X_{6}\right)$ and residential environment $\left(X_{11}\right)$ means that farmers with stronger financial capital will restrain their HW when they face greater risks to their living conditions. Conversely, the positive interaction impact between psychological condition $\left(X_{12}\right)$ and household income $\left(X_{6}\right)$ significantly indicates that financial capital can alleviate the negative impact of risk expectations on the HW. (3) The interaction impact between the highest level of education $\left(X_{8}\right)$ and psychological condition $\left(X_{12}\right)$ significantly inhibits the HW. In other words, farmers with stronger human capital are expected to face a stronger psychological risk to inhibit their exit.

\subsection{Robustness test}

This study refers to the practice of Sun et al. (2017) to conduct robustness testing by excluding the influence of extreme values. In all models, the samples of the highest and lowest levels of $5 \%$ each are removed according to the level of household income. Then, the probit model is carried out. After removing the extreme value samples, in any mode, all the key variables are consistent with the original sample, showing that the results obtained are robust.

\section{Discussion}

This study was based on the theoretical and empirical analysis of the three withdrawal models in Jinjiang City, Fujian Province. We aimed to fill the gap in previous studies that did not consider internal and external factors, such as household livelihoods and risk expectations. The results of this study are consistent with those of the existing literature. 
The control variables were also similar to those found in the existing literature. In the pooled and three individual models, age had a significant negative impact on the willingness for HW, reflecting the limited scope of labor activities and labor surplus of older rural households, a higher degree of dependence on homesteads, and weak withdrawal motivation (Sun et al., 2018). The population size in the pooled model has insignificant impact on HW. However, the individual models show different significant effects, in which the positive impact of the population size was confirmed in the asset replacement model. In this model, farmers can obtain 2-3 resettlement houses per household with an average of $150 \mathrm{~m}^{2}$ per person. Therefore, as the family becomes larger, the farmers are more likely to choose this mode to HW. The index replacement and monetary compensation models are the opposite because these two models of resettlement houses have a low number of asset attributes and limited appreciation space. When the total family size is larger, more elderly and children need support, and the cost of living upstairs from the homestead is higher. Sun et al. (2018) also believed that the uncertainty of life after HW will inhibit the willingness to withdraw, reflecting an increase in the cost of living after HW. Whether farmers are willing to withdraw from the homestead depends on the current property of the resettlement house.

Yang et al. (2021) indicated that farmers with higher natural capital may prefer to transfer their cultivated land. However, the present study found that the cultivated land in the pooled model has a significant negative impact on HW. This result is specifically reflected in the index replacement and monetary compensation models. The homestead areas in all the models have a significant negative impact on HW, which is in line with Hypothesis 1. In the asset replacement model, as farmers have more opportunities for non-agricultural operations and more profitable resources, their willingness for $\mathrm{HW}$ is more inhibited. The index replacement model was located in a traditional agricultural area with $90.76 \mathrm{hm}^{2}$ of cultivated land; however, most of the cultivated land has been contracted out. Farmers' dependence on agricultural income has gradually weakened. Moreover, homesteads play a major role in housing for farmers under this model. Most farmers carefully design their self-built buildings, and their awareness of the house as a "face" is deeply rooted, which will also inhibit their willingness for HW (left side of Figure 4). Alternatively, most farmers under the monetary compensation model rely heavily on agricultural production as their main source of income. The "upstairs effect" after HW may face problems, such as reduced agricultural production and inconvenient placement of farm tools. Therefore, households with more cultivated land area under the monetary compensation model are more reluctant for HW. Moreover, owing to the accelerated urbanization process, the homestead mainly realizes the residential function to facilitate the care of the elderly and children's education under this model.
In addition, the annual household income representing financial capital has insignificant impact on HW in the pooled model. Liu et al. (2020) found that farmers with a higher proportion of agricultural income have relatively weaker information acquisition capabilities. Therefore, they have lower expectations for the future value of homesteads and are more likely to engage in HW to obtain income. Contrarily, the asset replacement model revealed that financial capital promotes HW because of the large radiation and driving effect of the overall urban and rural development. Rural households with higher incomes living in cities and towns have a stronger awareness of household asset al.ocation and investment. Hence, they pay more attention to the asset attributes under the increasing maturity of the land market. Households with better family wealth in suburban villages and outer suburbs pay more attention to the long-term benefits of old-age care, summer vacations, and leisure brought by homesteads.

In addition, the testing of Hypothesis 3 showed that the inhibitory effect of human capital was confirmed only in the asset replacement model and not significant in the pooled model. The reasons are the more mature living facilities in the area and expectation of transforming to urban household registration and returning the value of housing assets, as indicated by Liu et al. (2020); therefore, they are more willing to engage in HW (right side of Figure 4). However, the promotion effect revealed in the index replacement and monetary compensation models is consistent with the view of Sun et al. (2018). In other words, farmers with higher education are more likely to engage in HW. In these two models, most household members with higher education levels work in other places. Then, those who remain in the community are still dependent on agriculture and have relatively lower levels of education. They are more dependent on homesteads; therefore, they are unwilling to engage in HW.

The changes in the external environment that farmers perceive affect their psychological expectations determine their willingness to participate in HW. We also found that, in Hypothesis 4, life risk expectation only has a significant negative impact on the monetary compen-

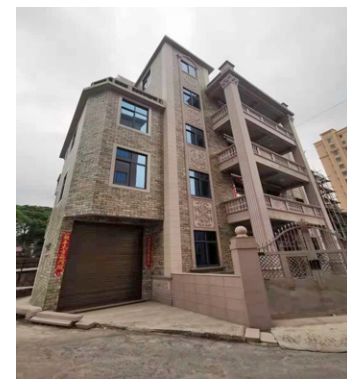

a)

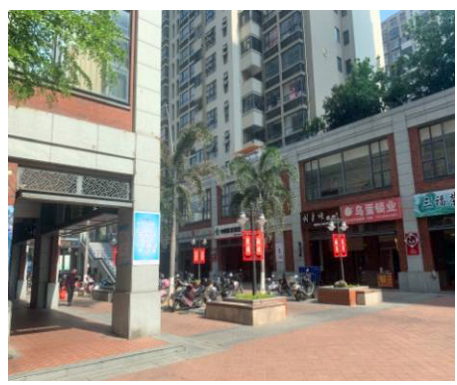

b)
Figure 4. (a) Well-designed housing under index replacement model of Q village (left side); (b) Well-designed and wellplanned facilities under the asset replacement model of $\mathrm{G}$ village (right side) 
sation model. The reason is that when more farmers are engaged in agricultural production with opportunities to develop a courtyard economy through urbanization, they will be less willing to withdraw. The risk expectation of social security had a significant negative impact on $\mathrm{HW}$ in all models. Hypothesis 5 was verified, and the literature also indicates that social security programs can reduce farmers' dependence on the social security function of land (Yang et al., 2021). This result confirms that households will be protected more after transitioning to urban household registration under the asset replacement model. In the other two models, the negative impact of risk expectation of social security on $\mathrm{HW}$ is because of concerns about inadequate safeguard policies. Moreover, the risk expectations of residential environments have significant negative impacts on $\mathrm{HW}$ in all models, thereby supporting Hypothesis 6. The degree of risk perception of living conditions will be alleviated whether an asset replacement model is built with a green ecological modern community or the index replacement or monetary compensation models. In other words, the spatial layout of the village is optimized after village reconstruction and comprehensive consolidation through the village collectives. Finally, the significant negative impact of the psychological condition referred to in Hypothesis 7 was verified in the pooled, asset replacement, and monetary compensation models. Owing to the differences in social communication between rural and urban communities (Chen et al., 2017), farmers cannot fully integrate with the surrounding environment, which inhibits their willingness to pursue HW.

In the empirical analysis of the interaction impact on HW, the interaction between natural capital and risk expectation in terms of living conditions is inconsistent with Hypothesis 8. However, the risk expectation in terms of living or psychological conditions validates this hypothesis. The actual survey found that farmers with higher arable land and homestead resources would inhibit their HW. However, as the attributes of the land become more prominent, the farmers will get a considerable income from the homestead. However, they are more worried about the risks of living and psychological conditions. The interaction between financial capital and risk expectations in terms of housing and psychological conditions has a negative impact. This result is consistent with the inference of Hypothesis 9 that the impact is uncertain. Farmers with better family wealth status pay more attention to the quality of the resettlement housing community. From another aspect, farmers with more financial capital have more diversified social relations networks and can better integrate into the new environment, which risks psychological conditions. In addition, the interaction impact between human capital and risk expectations is consistent with Hypothesis 10. The risk expectations in terms of housing conditions will strengthen the farmers' HW with high education levels, but the psychological risk expectations will inhibit the withdrawal of such groups.

\section{Conclusions and policy recommendations}

The function of homesteads has undergone major changes along with the changes in the rural social structure and farmers' livelihood model. Exploring the adaptability of farmers' livelihood structure and risk resistance, the three HW models can provide a realistic basis for scientifically and systematically promoting farmers' HW. We used the probit model to analyse the impact mechanism of farmers' livelihoods and risk expectations on HW behavior under three different models. Based on the SLA framework, we analysed the changes in farmers' livelihood capacity and risk environment after HW. Then, we discussed and compared the differences among the three models.

The empirical evidence indicated that the cultivated land and household income representing natural and financial capital, respectively, had significant inhibitory effects on HW in the index replacement and monetary compensation models. By contrast, they had positive effects on HW in the asset replacement model. In addition, the highest level of education, representing human capital, had a significant inhibitory effect on HW in the asset replacement model and positive effects on HW in the index replacement and monetary compensation models. In terms of risk expectations, the risk of living conditions only had a significant inhibitory effect on HW in the monetary compensation model. The risk expectations of social security and residential environment significantly inhibited HW in all three models. Psychological conditions only inhibited HW in the asset replacement and monetary compensation models. The interaction impact between capital and risk expectations on HW is also revealed.

Based on this study, the following policy recommendations are proposed:

Carry out a comprehensive survey of farmers' livelihood capital and risk expectations to facilitate the implementation of the HW policy. Considering the differences of policy effect in different homestead models, a comprehensive survey of the livelihoods and risk expectations to affected rural households should be carried out before the official implementation of the HW policy. Moreover, the resource endowments and risk expectations of rural households should be considered to carry out more detailed research. For example, if local governments want to implement the index replacement or monetary compensation models, they should start with the household with lower natural, lower financial, and stronger human capital, which can promote the policy's probability of success.

Propose relevant measures to suit local conditions to promote the improvement of farmers' sustainable livelihood ability. Given the high dependence of farmers on agricultural income under the index replacement and monetary compensation models, multiple compensation methods should be implemented after retiring. The objective is to further improve the employment skills training policy and broaden employment channels, such as labor export, the introduction of community factories, and the 
development of public welfare. Under the asset replacement and monetary compensation modes, the properties of homestead assets have become increasingly prominent. Hence, the economic value of the homestead itself, the value of the income from the loss of the homestead, and the cost of "upstairs" into the scope of compensation should be included. This case will increase the farmers' ability to withdraw from the homestead.

Comprehensively measure the impact of HW on farmers and improve the risk's controllability. The implementation of the monetary compensation and index replacement models should be based on improving the farmers' welfare. The objectives are to further improve the supporting system of public resources and public facilities, gradually integrate the rural subsistence allowance, endowment insurance, medical insurance, and others into the urban social security system, and improve farmers' welfare. At the same time, the quality of public services and participation in community culture should be improved through the development of a variety of community activities. Furthermore, the following are proposed: improve community governance, promote the contact between farmers and citizens to help farmers to further integrate into the community, and reduce the risk of farmers' transformation adaptability.

\section{Funding}

This research was funded by Ministry of Education Foundation of Humanities and Social Sciences (grant number 19YJA630043).

\section{Author contributions}

Fachao LIANG conceived the study and were responsible for the design and development of the data analysis. Caiyun LIN were responsible for data collection and interpretation. Sheng-Hau LIN was responsible for manuscript's revision and wrote the first draft of the article.

\section{Disclosure statement}

Authors do not have any competing financial, professional, or personal interests from other parties.

\section{References}

Allison, E. H., \& Horemans, B. (2006). Putting the principles of the sustainable livelihoods approach into fisheries development policy and practice. Marine Policy, 30, 757-766. https://doi.org/10.1016/j.marpol.2006.02.001

Baffoe, G., \& Matsuda, H. (2018). An empirical assessment of households livelihood vulnerability: the case of rural Ghana. Social Indicators Research, 140, 1225-1257. https://doi.org/10.1007/s11205-017-1796-9

Breusch, T. S., \& Pagan, A. R. (1979). A simple test for heteroscedasticity and random coefficient variation. Econometrica, 47, 1287-1294. https://doi.org/10.2307/1911963
Cao, Q., Sarker, M. N. I., \& Sun, J. (2019). Model of the influencing factors of the withdrawal from rural homesteads in China: application of grounded theory method. Land Use Policy, 85, 285-289. https://doi.org/10.1016/j.landusepol.2019.04.013

Cetinkaya, G., Kamnu, A., \& Nakamura, K. (2014). Sustainable development and natural resource management: an example from Köprülü Kanyon National Park, Turkey. Sustainable Development, 22(1), 63-72. https://doi.org/10.1002/sd.528

Chen, H., Zhao, L., \& Zhao, Z. (2017). Influencing factors of farmers' willingness to withdraw from rural homesteads: a survey in Zhejiang, China. Land Use Policy, 68, 524-530. https://doi.org/10.1016/j.landusepol.2017.08.017

Chen, M. Q., Guang, F. Y., \& Lu, Y. F. (2018). Livelihood capital differentiation and farmers' willingness to homestead circulation: based on empirical analysis of Jiangxi Province. Journal of Agro-Forestry Economics and Management, 17(1), 82-90 (in Chinese).

Deng, Q., Li, E., \& Zhang, P. (2020). Livelihood sustainability and dynamic mechanisms of rural households out of poverty: an empirical analysis of Hua County, Henan Province, China. Habitat International, 99, 102160.

https://doi.org/10.1016/j.habitatint.2020.102160

Department for International Development. (1999). Sustainable livelihoods guidance sheets (Numbers 1-8). https://www.livelihoodscentre.org/documents/114097690/114438878/Sustain able+livelihoods+guidance+sheets.pdf/594e5ea6-99a9-2a4ef288-cbb4ae4bea8b?t=1569512091877

Donaldson, R., \& Lord, R. (2018). Can brownfield land be reused for ground source heating to alleviate fuel poverty? Renewable Energy, 116A, 344-355.

https://doi.org/10.1016/j.renene.2017.09.037

Durbin, J. (1954). Errors in variables. Review of the International Statistical Institute, 22, 23-32. https://doi.org/10.2307/1401917

Fan, W., \& Zhang, L. (2019). Does cognition matter? Applying the push-pull-mooring model to Chinese farmers' willingness to withdraw from rural homesteads. Papers in Regional Science, 98(6), 2355-2369. https://doi.org/10.1111/pirs.12462

Hausman, J. (1978). Specification tests in econometrics. Econometrica, 46(6), 1251-1271. https://doi.org/10.2307/1913827

Hu, Y., Yang, C., Dong, W., Ql, Q., Zhang, Y., \& Lin, S. (2020). Farmers' homestead exit behavior based on perceived value theory: a case of Jinzhai County in Anhui Province. Resources Science, 42(4), 685-695 (in Chinese). https://doi.org/10.18402/resci.2020.04.08

Huang, C., \& Chen, C. W. (2016). Social risk and governance mechanism on land development in the process of urbanization. Economic Geography, 36(4), 147-151 (in Chinese).

Huang, X., Huang, X., He, Y., \& Yang, X. (2017). Assessment of livelihood vulnerability of land-lost farmers in urban fringes: a case study of Xi'an, China. Habitat International, 59, 1-9. https://doi.org/10.1016/j.habitatint.2016.11.001

Huang, X., Li, H., Zhang, X., \& Zhang, X. (2018). Land use policy as an instrument of rural resilience - the case of land withdrawal mechanism for rural homesteads in China. Ecological Indicators, 87, 47-55. https://doi.org/10.1016/j.ecolind.2017.12.043

Jinjiang Statistics Bureau. (2019). National Economic and Social Development Statistical Bulletin. http://www.jinjiang.gov.cn/ xxgk/tjxx/tjgb/202004/t20200413_2203215.htm

Kuang, F., Jin, J., He, R., Ning, J., \& Wan, X. (2020). Farmers' livelihood risks, livelihood assets and adaptation strategies in Rugao City, China. Journal of Environmental Management, 264, 110463. https://doi.org/10.1016/j.jenvman.2020.110463 
Kumar, P., Kumar, P., \& Garg, R. K. (2021). A study on farmers' satisfaction and happiness after the land sale for urban expansion in India. Land Use Policy, 109, 105603.

https://doi.org/10.1016/j.landusepol.2021.105603

Li, H., \& Zhang, A. L. (2019). The measurement and dynamic changes of farmers' welfare before and after rural homestead withdrawal - an empirical analysis of 201 farmers in the homestead reform pilot, Deqing County. Journal of Agrotechnical Economics, 2019(7), 79-90 (in Chinese).

Li, W., Shuai, C., Shuai, Y., Cheng, X., Liu, Y., \& Huang, F. (2020). How livelihood assets contribute to sustainable development of smallholder farmers. Journal of International Development, 32(3), 408-429. https://doi.org/10.1002/jid.3461

Liang, F., \& Lin, C. (2021). Operation mechanism, mode comparison and path optimization of rural homestead withdrawal with compensation in economically developed. China Rural Survey, 2021(3), 1-14 (in Chinese).

Liang, F. C., \& Lin, C. Y. (2019). Research on the risk evaluation and prevention measures of rural residential land withdrawal under different modes: a case study of Jinjiang City, Fujian Province. Research of Agricultural Modernization, 40(6), 1011-1020.

Lin, C., \& Guo, Y. J. (2020). The research review on function of rural residential land and enlightenment to rural revitalization strategy. Reform of Economic System, 2020(04), 194-199 (in Chinese).

Liu, W., Li, J., Ren, L., Xu, J., Li, C., \& Li, S. (2020). Exploring livelihood resilience and its impact on livelihood strategy in rural China. Social Indicators Research, 150, 977-998. https://doi.org/10.1007/s11205-020-02347-2

Liu, Y. T., Chen, M. Q., \& Guang, F. Y. (2019). Social network, information cost and the influence of farmers' willingness to adopt ecological farming. Journal of China Agricultural University Social Sciences, 24(11), 250-258 (in Chinese).

Loures, L., \& Vaz, E. (2018). Exploring expert perception towards brownfield redevelopment benefits according to their typology. Habitat International, 72, 66-76. https://doi.org/10.1016/j.habitatint.2016.11.003

Mao, S., Qiu, S., Li, T., \& Tang, M. (2020). Rural households' livelihood strategy choice and livelihood diversity of main ethnic minorities in Chongqing, China. Sustainability, 12, 8166. https://doi.org/10.3390/su12198166

Qu, Y. B., Jiang, G. H., Ma, W. Q., \& Li, Z. (2021). How does the rural settlement transition contribute to shaping sustainable rural development? Evidence from Shandong, China. Journal of Rural Studies, 82(2), 279-293.

https://doi.org/10.1016/j.jrurstud.2021.01.027

Sen, A. (1999). Development as freedom. Oxford University Press.

Shan, Z., \& Feng, C. (2018). The redundancy of residential land in rural China: the evolution process, current status and policy implications. Land Use Policy, 74, 179-186.

https://doi.org/10.1016/j.landusepol.2017.07.031

Shang Guan, C., Feng, S., Lu, H., \& Qu, F. (2017). Impact of rural residential land replacement on farmers' welfare under different modes - taking ten thousand hectare fertile farmland construction in Jiangsu Province as an example. China Soft Science, 2017(12), 87-99 (in Chinese).

Shi, P., \& Yu, J. (2021). Impact of risk expectation, citizenization perception, and farmers'cognition on the relocated rural households' homestead withdrawal. Resources Science, 43(7), 1387-1402 (in Chinese).

https://doi.org/10.18402/resci.2021.07.09

Sun, G., Li, Q., \& Li, C. (2017). The impact of financial literacy on credit default of rural households in less developed ar- eas: an investigation in Xinjiang Uygur Autonomous Region. China Rural Survey, 2017(4), 1-15 (in Chinese).

Sun, H. L., Liu, R. L., \& Liu, X. Z. (2020). Impact of rural construction the livelihood sustainability of household lifted out of poverty: data analysis of 2660 pro-poverty families in poverty-stricken areas. Journal of Northwest A\&F University (Social Science Edition), 20(05), 56-67 (in Chinese).

Sun, P., \& Zhao, K. (2020). Effect of social capital on farmers' behavior of quitting rural residential land: a case of 606 farmers' samples in Jinzhai County, Anhui Province. Journal of Nanjing Agricultural University (Social Sciences Edition), 20(5), 128-141 (in Chinese).

Sun, P. F., Zhao, K., Zhou, S. Q., \& He, J. (2019). Risk expectation, social network and farmers' behavior of rural residential land exit: based on 626 rural households' samples in Jinzhai County, Anhui Province. China Land Science, 33(04), 42-50 (in Chinese).

Sun, X., Zhang, Z., \& Zhang, Y. (2018). Factors influencing farmer's decision-making behavior on rural construction land transformation. Sustainability, 10(11), 4288.

https://doi.org/10.3390/su10114288

Tang, P., Chen, J., Gao, J., Li, M., \& Wang, J. (2020). What role(s) do village committees play in the withdrawal from rural homesteads? Evidence from Sichuan Province in Western China. Land, 9, 477. https://doi.org/10.3390/land9120477

Wang, J., \& Zhu, L. (2018). Study on the circulation willingness of rural residential land an farmer sustainable livelihoods. Chinese Journal of Agricultural Resources and Regional Planning, 39(6), 165-170 (in Chinese).

Wang, N., Hao, J. M., Li, M., \& Chen, A. (2019). Zoning and potential of rural housing land consolidation in Hebei Province under background of livelihoods transformation. Transactions of the Chinese Society of Agricultural Engineering, 35(9), 255-264 (in Chinese).

Wang, W. Q., Lan, Y. Q., Yu, L. H., Gong, H., \& Wang, X. (2020). Impact of rural households' livelihood capital endowment on poverty alleviation and income increase of rural land consolidation in different modes: evidence from Enshi, Hubei Province and Bijie, Guizhou Province. China Land Science, 34(04), 86-94 (in Chinese).

$\mathrm{Wu}, \mathrm{D}$. M. (1973). Alternative tests of independence between stochastic regressors and disturbances. Econometrica, 41(4), 733-750. https://doi.org/10.2307/1914093

$\mathrm{Wu}, \mathrm{D} . \mathrm{M}$. (1974). Alternative tests of independence between stochastic regressors and disturbances: finite sample results. Econometrica, 42(3), 529-546. https://doi.org/10.2307/1911789

Wu, L., \& Wu, Z. (2021). Effect of homestead withdrawal on family welfare: from the perspective of family risk taking capacity. Resources Science, 43(7), 1479-1491 (in Chinese). https://doi.org/10.18402/resci.2021.07.16

Wu, Z. B., \& Wu, L. J. (2020). Research on the bilateral matching between the development ability of peasant household and the withdrawal mode of the homestead. Journal of Agrotechnical Economics, 41(9), 128-135 (in Chinese).

Xu, D., Deng, X., Guo, S., \& Liu, S. (2019). Sensitivity of livelihood strategy to livelihood capital: an empirical investigation using nationally representative survey data from rural China. Social Indicators Research, 144, 113-131. https://doi.org/10.1007/s11205-018-2037-6

Yang, G. Y., Jiang, Q., Tian, T., \& Xu, W. (2019). Household welfare change of migrant workers returning home to build houses: based on a survey of migrant worker source areas in Fujian Province. Resources Science, 41(7), 1213-1226 (in Chinese). 
Yang, H., Huang, K., Deng, X., \& Xu, D. (2021). Livelihood capital and land transfer of different types of farmers: evidence from panel data in Sichuan Province, China. Land, 10, 532. https://doi.org/10.3390/land10050532

You, H., \& Zhang, X. (2017). Sustainable livelihoods and rural sustainability in China: ecologically secure, economically efficient or socially equitable? Resource, Conservation and Recycling, 120, 1-13.

https://doi.org/10.1016/j.resconrec.2016.12.010

Zhang, T., Zhang, A., \& Deng, S. (2016). Expected return, risk expectation and residential land quitting behavior among farmers in Songjiang and Jinshan Districts, Shanghai. Resources Science, 38(08), 1503-1514 (in Chinese). https://doi.org/10.18402/resci.2016.08.09

Zhang, Y., Westlund, H., \& Klaesson, J. (2020). Report from a Chinese village 2019: rural homestead transfer and rural vitalization. Sustainability, 12(20), 8635. https://doi.org/10.3390/su12208635

Zhou, L., Li, H. M., \& Li, P. (2020a). Impact of livelihood capital on the choice of livelihood strategy for resettled farmers: based on the survey of resettled farmers in Hunan Province. Economic Geography, 40(11), 167-175 (in Chinese).

Zhou, T., Jiang, G., Li, G., Zhoum, D., \& Qu, Y. (2020b). Neglected idle rural residential land (IRRL) in metropolitan suburbs: spatial differentiation and influencing factors. Journal of Rural Studies, 78, 163-175.

https://doi.org/10.1016/j.jrurstud.2020.06.020

Zhou, Y. H., Fang, T. T., \& Li, L. (2021). Decision-making mechanism of farmers' homestead exit based on the TAM-TPB framework. China Land Science, 43(1), 148-160 (in Chinese). https://doi.org/10.18402/resci.2021.01.12

Zhu, F. K., Zhang, F. R., Li, C., \& Zhu, T. (2014). Functional transition of the rural settlement: analysis of land-use differentiation in a transect of Beijing, China. Habitat International, 41(1), 262-271.

https://doi.org/10.1016/j.habitatint.2013.07.011

Zhu, X. H., \& Cai, J. (2016). The influences of perceived values and capability approach on farmers' willingness to exit rural residential land and its intergenerational difference. China Land Science, 30(9), 64-72 (in Chinese). 